DOI : 10.24260/khatulistiwa.v9i1.1255

\title{
TUDANG SIPULUNG IN MUSLIM COMMUNITY OF PENITI LUAR (IDENTITY, ISLAMIC VALUES, AND CHARACTER BUILDING)
}

\author{
BAYU SURATMAN \\ Universitas Islam Negeri (UIN) Sunan Kalijaga Yogyakarta \\ Email:bayusuratman2003@gmail.com \\ SYAMSUL KURNIAWAN \\ Institut Agama Islam Negeri (IAIN) Pontianak, \\ syamsulkurniawan001@gmail.com
}

\section{HIGHLIGH}

- The tradition of the Tudang Sipulung developed as the local wisdom of the Muslim community in the Peniti Luar Village was inspired by Islamic values

\section{ARTICLE HISTORY}

Submitt : 15 Feb 2019

Revision : 17 Mar 2019

Revision : 20 Mar 2019

Minor

Accepted : 28 Mar 2019

Published : 30 Mar 2019

\section{ABSTRACT}

The focus of this article is to discuss some basic questions: First, why muslim communities in Peniti Luar are still retaining tradition of Tudang Sipulung. Second, how do muslim communities in the village of Peniti Luar carry out the Tudang Sipulung. What Islamic values are relevant in Tudang Sipulung. And the fourth is what is its relevance in building character. This paper is resulted a study in which the data obtained from interviews and observations on the location of the research.

Keyword : Tudang Sipulung, Identity, Islamic Values, Character Building

\section{C2019 Khatulistiwa All Rights Reserved}

KHATULISTIWA: Journal of Islamic Studies Vol. 9, No. 1. March 2019
DOI: $10.24260 /$ khatulistiwa.v9i1.1255

Tudang Sipulung in Muslim Community of Peniti Luar (Identity, Islamic Value and Character Building) 


\section{A. INTRODUCTION}

For a long time the people of West Kalimantan identified people with each other with unique identification (Zainuddin, 2009: 256). West Kalimantan is a province that has a wide variety of cultural cultures in which traditions is carried out by the community without any encouragement and coercion, or in Pieree Bourdieu's terminology namely habitus. According to Pierre Bourdieu's definition (2012: xvi), habitus is long-lasting in the sense of surviving along a certain period of time from the life of an agent. Agents are people who carry out traditions that provide the means, thoughts, and time in the implementation of traditions. Mohammad Adib (2012: 101) states that habitus can be directed towards the goals and results of certain actions but without any conscious intention in achieving these results. Arizal Mutahir (2011: 65) states that habitus is pre-conscious, it is more than spontaneous but not a mechanistic movement that neglects historical background. Habitus is formed by social conditions where it produced.

Culture in society will shape and influence actions and thought patterns in a society, both ethnic and religious identity. Habit or habitus in a culture contributes to personality in this case the Islamic personality. To build an Islamic personality we must realize the application of the environment through culture and the implementation of traditions that instill Islamic values. So that through the culture of society can practice Islamic teachings in a social order that is, culture.

Besides that, Moh. Haitami Salim (2012: 6) said that religion and ethnicity are two different things. Religion concerns the beliefs that embraced and even personal. While ethnicity concerns the identity of the origin of one's descendants. Because religion intersects with matters of faith, it can change with the beliefs of its followers. This means that someone can be Muslim today and then tomorrow he will convert to another religion. In this study the identity of the Peniti Luar community, which is predominantly Bugis, was able to eliminate their Bugis name identity in carrying out the tradition, but they still in the package of the Bugis

KHATULISTIWA: Journal of Islamic Studies Vol. 9, No. 1. March 2019
DOI: 10.24260/khatulistiwa.v9i1.1255

Tudang Sipulung in Muslim Community of Peniti Luar (Identity, Islamic Value and Character Building) 
tradition. So that the implementation does not only include the Bugis tribe but there is the Sambas Malay community.

One of the Bugis traditions is Tudang Sipulung. It is still work in the village of Peniti Luar in Mempawah Regency, West Kalimantan. Tudang Sipulungtradition carried out by community to express their gratitude to Allah SWT for giving them the confidence to start a new year in the cultivation of crops. Tudang Sipulung carried out by the entire of Peniti Luar community to start rice farming. So that the implementation of the Sipulung tradition is not only followed by Bugis people but people with different ethnic backgrounds. The implementation of the Tudang Sipulung is eating together on the ground as a ritual for beginning to farm the rice. It is not only limited to eat together on the ground, but has series of events: one of them is Barzanji(read the book of Rasullah SAW's history) which is held at the local Surau (alternative mosque). In addition, Bepapas against rice seeds are also found in this tradition. The implementation is a series of events are not separated.

So far, studies related to the identity of Muslims and ethnicity in West Kalimantan have been carried out, such as Saripaini \& Yusriadi about the Identity of the Bugis in Dabong, West Kalimantan; Moh. Haitami Salim in his book, "Islam and Ethnicity in West Kalimantan"; and Hermansyah through his books he wrote on Islam and Malays in Borneo. There are also several writings of research results relating to farming activities in Muslim communities in West Kalimantan, e.g. Wewen Darmawan, Amrazi Zakso, and Gusti Budjang, "The fading of the cultural values of proboscis in agriculture in rural communities"; Syamsul Kurniawan and Bayu Suratman, "Farming rice for the Sambas Malays: Local Wisdom, Islamic Values, and Character Building”. With the intention of completing the previous research above, this study explores Islamic values contained in the implementation of the traditional Tudang Sipulung tradition and the identity of Muslim communities in Peniti Luar Village.

This research was conducted in the Peniti Luar Village, Siantan district, Mempawah Regency, West Kalimantan Province. The place where the tradition of Tudang Sipulung is still being carried out. The focus of this research is to discuss numbers of basic questions: First, why the Muslim community in Peniti Luar still maintains the Tudang Sipulung? Secondly, how the Muslim community in the village of Peniti Luar carried out a Tudang Sipulungtradition?;Thirdly,

KHATULISTIWA: Journal of Islamic Studies

Vol. 9, No. 1. March 2019
DOI: 10.24260/khatulistiwa.v9i1.1255

Tudang Sipulung in Muslim Community of Peniti Luar (Identity, Islamic Value and Character Building) 
what Islamic values are relevant in Tudang Sipulung?; and the Fourth,what is their relevance in building character?

This paper is resulted from a study in which the data obtained from interviews and observations on the location of the research conducted in depth. This paper uses a qualitative study where the data is obtained from interviews and observations on the location of research conducted in depth.

\section{B. METHOD}

This paper uses a qualitative study where the data is obtained from interviews and observations on the location of research conducted in depth. This research was conducted in the Peniti Luar Village, Siantan district, Mempawah Regency, West Kalimantan Province. The place where the tradition Tudang Sipulung is still being carried out. The focus of this research is to discuss numbers of basic questions: First, why the Muslim community in Peniti Luar still maintains the Tudang Sipulung? Secondly, how the Muslim community in the village of Peniti Luar carried out a Tudang Sipulungtradition?;Thirdly, what Islamic values are relevant in Tudang Sipulung?; and the Fourth,what is their relevance in building character?

\section{RESULT AND DISCUSSION}

\section{Objective Conditions of Muslim Community Peniti Luar Village}

Peniti Luar Village is one of the villages located in Siantan District, Mempawah Regency. At present Peniti Luar Village has three hamlets, namely: Hamlet of Karya Bhakti which consists of 3 RTs and 2 RWs, the hamlet of Panca Bhakti has 4 RTs and 1 RW and the hamlet of Taruna Bhakti has 4 RTs and 2 RWs. The area of Peniti Luar village reaches 29.54 HA. Geographically, in the North side the Peniti Luar village is bordered by the Sungai Burung Village, so Sungai Nipah Village is border in the south, Natuna Sea in the West, and Peniti Dalam 1 Village to the east.

The number of people in the Peniti Luar village is 2,762. The number of men is 1,309 people and women are 1,453 people with a number of 780 family heads. The number consists of three hamlets, namely, Karya Bhakti, Panca Bhakti and Taruna Bhakti. If you look at the

KHATULISTIWA: Journal of Islamic Studies

Vol. 9, No. 1. March 2019
DOI: 10.24260/khatulistiwa.v9i1.1255

Tudang Sipulung in Muslim Community of Peniti Luar (Identity, Islamic Value and Character Building) 
work of Muslim communities in Peniti Luar Village, the majority are farmers and gardeners. For farmers, the village community planted rice while farming the village community planted coconut. (Village office data, 2017).

Based on data from the Peniti Luar Village, almost $83 \%$ of people the Peniti Luar are Farming and gardening. Peniti Luar Village's people is farming rice, while the average gardening is coconut. For coconut, almost all people have coconut plantations. This can be seen from the number of coconut plantations. In addition, around 5.7\% of the Peniti Luar Village work in the sea as a profession. While around $11.3 \%$ of Muslim communities in the Outer Peniti Village are in other fields.

The condition of education in the Peniti Luar Village can be categorized quite well. In the Peniti Luar village it consists of 3: MTs 1 Primary School named Ar-Raudhatul Islamiyah and 1 MA Ar-Raudhatul Islamiyah under one roof. As for PAUD, it was only established in 2017. In Peniti Luar Village, it still runs a religious tradition that runs lively and tends to be hybrid. According to Syamsul Kurniawan (2018: 334), hybrid is an acculturation between local wisdom and Islam so that it breeds hybrid local wisdom. This can be seen from the activities carried out by the people in the Peniti Luar village. Various religious activities are here, for example: 1) Barzanji tradition every Friday night; 2) There is a TPA (Qur'anic Teaching institution for children in every mosque; 3) Study Religion every Monday night; 4) Eat Sipulung which is done every time you start planting rice; and, Hadrahactivities and religious arts.

Teenagers and children in Muslim communities in Peniti Luar Village are also enthusiastic in carrying out religious teachings. It can be seen that every the maghrib time the children gather and recite at the Surau and the mosque. The places of worships have good facilities for their activities.

\section{Muslim Community Identity of The Peniti Luar}

The majority of Community in Peniti Luar Village is Bugis. Pelras (in Saripaini \& Yusriadi, 2016: 170) says that Bugis people are known as migrant communities in the archipelago. The Bugis community originating from the island of Sulawesi migrated and spread widely in West Kalimantan. Syamsul Kurniawan (2013: 107) mentions that Bugis people are

KHATULISTIWA: Journal of Islamic Studies

Vol. 9, No. 1. March 2019
DOI: $10.24260 /$ khatulistiwa.v9i1.1255

Tudang Sipulung in Muslim Community of Peniti Luar (Identity, Islamic Value and Character Building) 
reliable seafarers, so it is not surprising that there are among the descendants of the Bugis descendants of Sulawesi in West Kalimantan. Compare that with the view of Hasse J (2009: 236) which assumes they are farmers and not sailors. But these two views actually complement each other. This reason is based on the fact that the Bugis maritime activities really developed in the 18th century. The Bugis who had previously sailed then shifted as master farmers.

Maritime activities are only liked by Bugis people in the coastal areas whose nature is based on economic motives and geographical factors where they reside. So that the quantity is no longer the majority. In connection with these two views, the researcher concluded that Bugis, one of the tribes that has a high work ethic, it can be seen that they are able to adapt and survive both in the maritime and in agriculture.

In addition, the relationship that the Bugis tribe and other tribes have established in West Kalimantan has a strong emotional bond. Especially if there is a mixed marriage between ethnic Bugis and ethnic Malays. The majority of Peniti Luar ethnic Bugis are very open to other ethnic groups. This can be seen from the daily lives of Bugis people in the Peniti Luar Village. Based on the results of interviews and observations there were several people from the Peniti Luar Village who came from Sambas Malay. The existence of the Sambas Malay community lives in the Peniti Luar Village because in about 1970 the Sambas people cleared land in the Peniti Luar Village and settled until now. For now the Sambas Malay community still uses Sambas Malay language when meeting other Sambas Malay people. Rizal Mustansyir (2015: 9) Sambas Malay community also spread to various other regions or regencies in West Kalimantan even found outside the island of West Kalimantan.

In addition, the Sambas Malay community outside Sambas and West Kalimantan districts formed associations using both the Sambas and West Kalimantan communities to gather both in gathering, arts and other cultural events.According to Mr. Jumadi (39) his parents came from Sungai Kelambu Village, Tebas District. In addition, the same thing was also revealed by Anen (18). According to him, his parents also lived in the Peniti Luar Village because they already owned land so they settled in the Peniti Luar Village. According to Yusriadi (2015: 97) Islam was an important part of Malay identity and Islam is a sign that they are Malay. In everyday life, Sambas Malays use Sambas Malay language in speaking. This is

KHATULISTIWA: Journal of Islamic Studies

Vol. 9, No. 1. March 2019
DOI: 10.24260/khatulistiwa.v9i1.1255

Tudang Sipulung in Muslim Community of Peniti Luar (Identity, Islamic Value and Character Building) 
reinforced by the theory built by Hermansyah (2015: 1) to refer to Malays as adherents of Islamic teachings. In addition, Islam is a marker of the identity of someone's Malayness. Malay and Islam cannot be separated because it has become an identity of Malay.

Based on the observations of the researchers and the results of interviews of at least 10 heads of families who came from Sambas Malay in the Peniti Luar village. In fact, when researchers visited MTs and MA Ar-Raudhatul Islamiyah in Peniti Luar village many students could speak Sambas Malay. Aside from opening up other factors, the Sambas Malay community settled in the Peniti Luar village because of a marriage. According to Mrs. Sela (37) said that the reason for being in Peniti Luar was due to being married to one of the community of the Peniti Luar Village and settled until the present. Melayu Sambas in Peniti Luar Village did not eliminate the identity of the origin of the descendants even though the community was born in the Peniti LuarVillage. One of the descendants of Malay descent Sambas Ryan (28) said that his parents came from Sambas and at home he used the Sambas language so that he could speak Sambas until now.

Dendi (14) also said the same thing when his parents used the Sambas language while when they were outside or in the community both parents used Pontianak Malay language. In addition, Diwan (16) said that he and his brother were born in the Peniti Luar village and both of his parents were native to Sambas Malay. However, until now the family often returns to the village even though only once a year. Likewise delivered by Bayu (15) said that his parents were Sambas Malay so that in his family's house he spoke using Sambas Malay while for his family the Pontianak Malay language was also used. If you see the theory built by Yusriadi (2015: 77) about identity arises because people outside that gives identity to a person or group of people with a certain identity or called "Authority defined".

According to Mr. Jumadi (39), it was revealed that currently Sambas Malay in the Peniti Luar Village is following the activities or traditions of the Peniti Luar Village community. However, to speak to the Sambas Malay community they still use Sambas Malay language. So that not a few Bugis people in Peniti Luar Village can speak using the Sambas language. In this case, the Sambas Malay community in the Peniti Luar Village follows local traditions both in religion and society. One of Bugis community who can speak using the Sambas language Mr.

KHATULISTIWA: Journal of Islamic Studies

Vol. 9, No. 1. March 2019
DOI: $10.24260 /$ khatulistiwa.v9i1.1255

Tudang Sipulung in Muslim Community of Peniti Luar (Identity, Islamic Value and Character Building) 
Ali (55) and Mr. Sulaiman (51) can speak Sambas when speaking with the Sambas Malay community.

In terms of carrying out the tradition between the Sambas Malay people and Bugis joined together so that in tradition there is no difference. Thus, for the Peniti Luar community, there is no longer a traditional term from a particular tribe. As long as the community resides in the Peniti Luar village and there are Muslim, the tradition carried out includes part of the community. This is relevant to the view of Budi Santoso (2006: 44) that identity contains similarities and differences. Identity means a character that distinguishes an individual or group or equality in identity arises when it has similarities with individuals and groups. This is in accordance with the theory built by Zainuddin (2009: 253) identity related to something that is owned, something unwittingly becomes the most important part in a group member.

\section{Tudang Sipulungin Muslim's Village Communities}

Tudang Sipulung is a traditional tradition of the Bugis people in the Peniti Luar Village, Siantan District, Mempawah Regency and has been implemented for quite a long time and has fallen down. The implementation of the Tudang Sipulung is carried out once a year by the community of the Peniti Luar Village. In general, the tradition of the Tudang Sipulung was not only carried out by the Bugis community, but was also attended by the entire community of the Peniti Luar Village, especially the community of connecting road between the hamlets of Panca Bhakti and Taruna Bhakti in the Peniti Luar Village. This tradition is carried out to begin planting rice. According to Mr. Fauzi (44), one of the religious leaders of the Peniti Luar Village said that the Sipulung had the meaning of sitting together,and the community called it eating Sipulung.

Carrying out a tradition of Tudang Sipulung or eating Sipulung has a historical story, that is, when in the time of the Prophet Solomon who had an agreement with the Genie class. According to Mr. Fauzi (44) all of Geniesare submit to the prophet Sulaiman and the genie promised not to disturb the grandchildren of the prophet Adam and if the genie violated then the genie would get sin to Allah and rebellion to the prophet Muhammad. The purpose of

KHATULISTIWA: Journal of Islamic Studies

Vol. 9, No. 1. March 2019
DOI: $10.24260 /$ khatulistiwa.v9i1.1255

Tudang Sipulung in Muslim Community of Peniti Luar (Identity, Islamic Value and Character Building) 
carrying out the meal is to remind the genie of the agreement that was made and not to feed the genie. If seen in the implementation of eating Sipulung, start by reading the prayer of the Prophet Solomon.

Sipulung food is carried out in one of the community's rice fields. Based on the results of the observations, the researchers ate the rice cake close to the trench in the rice fields. Before starting the meal, the whole community brought free-range chicken, rice, cooking utensils and spices to cook chicken. Basically, the community was not required to bring chicken but it was recommended to bring the most important food during the community meal program. Eating a Sipulung is only followed by men, usually the head of the family or male representatives of each house.

Sipulung food is done in the morning after the cooking equipment is collected and all the men are usually the head of the family gathered with chicken. Then one of the religious leaders recited a prayer facing the rice fields. After reading the prayer the religious leader cut

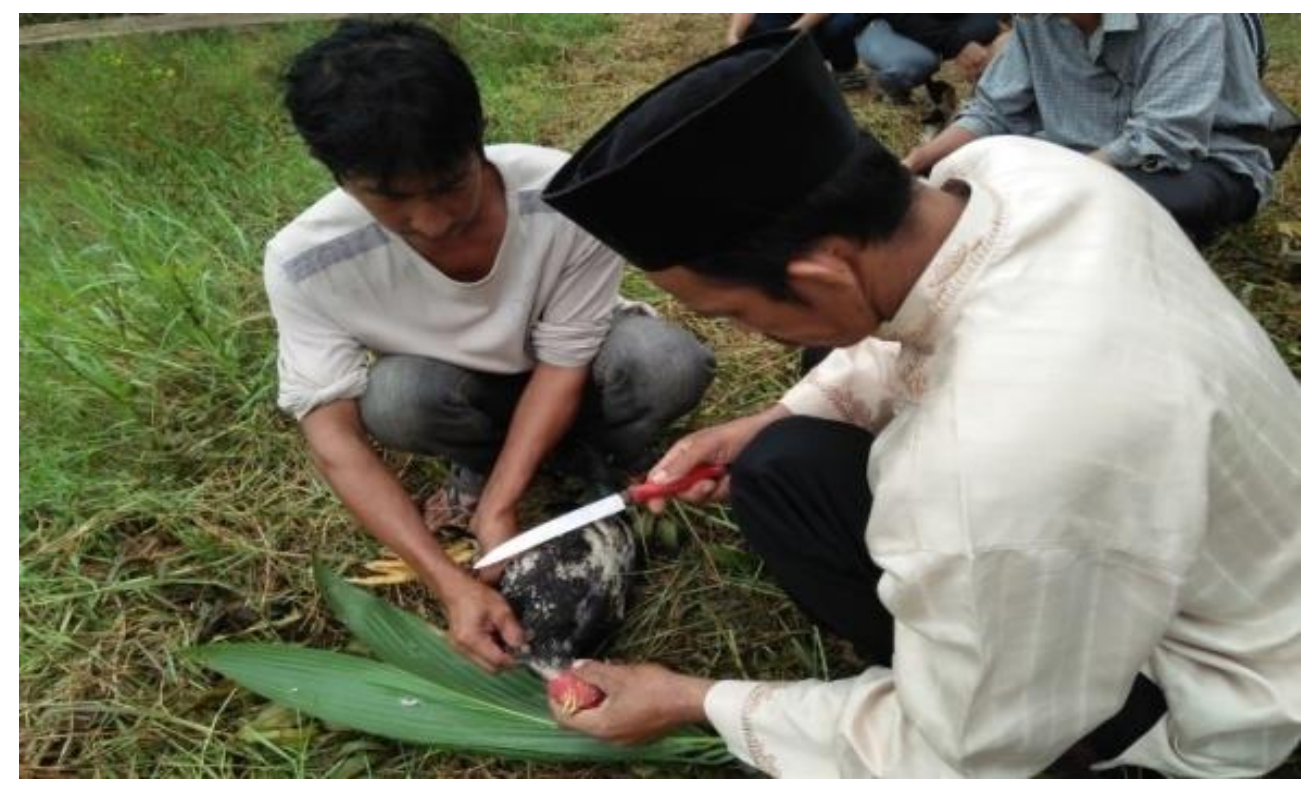

the chicken.

Figure.1

Cutting off chickens by religious leaders

(photo author documentation)

KHATULISTIWA: Journal of Islamic Studies

Vol. 9, No. 1. March 2019
DOI: $10.24260 /$ khatulistiwa.v9i1.1255

Tudang Sipulung in Muslim Community of Peniti Luar (Identity, Islamic Value and Character Building) 
After the religious leaders cut the chickens, all the men removed the chicken feathers that had been cut and cleaned them in line. To cook and clean chicken is done in the location of rice fields where the prayer is recited. While cleaning the chicken, the other men turn on the fire to cook the chicken and indeed in its implementation using fire wood and coconut midribs.

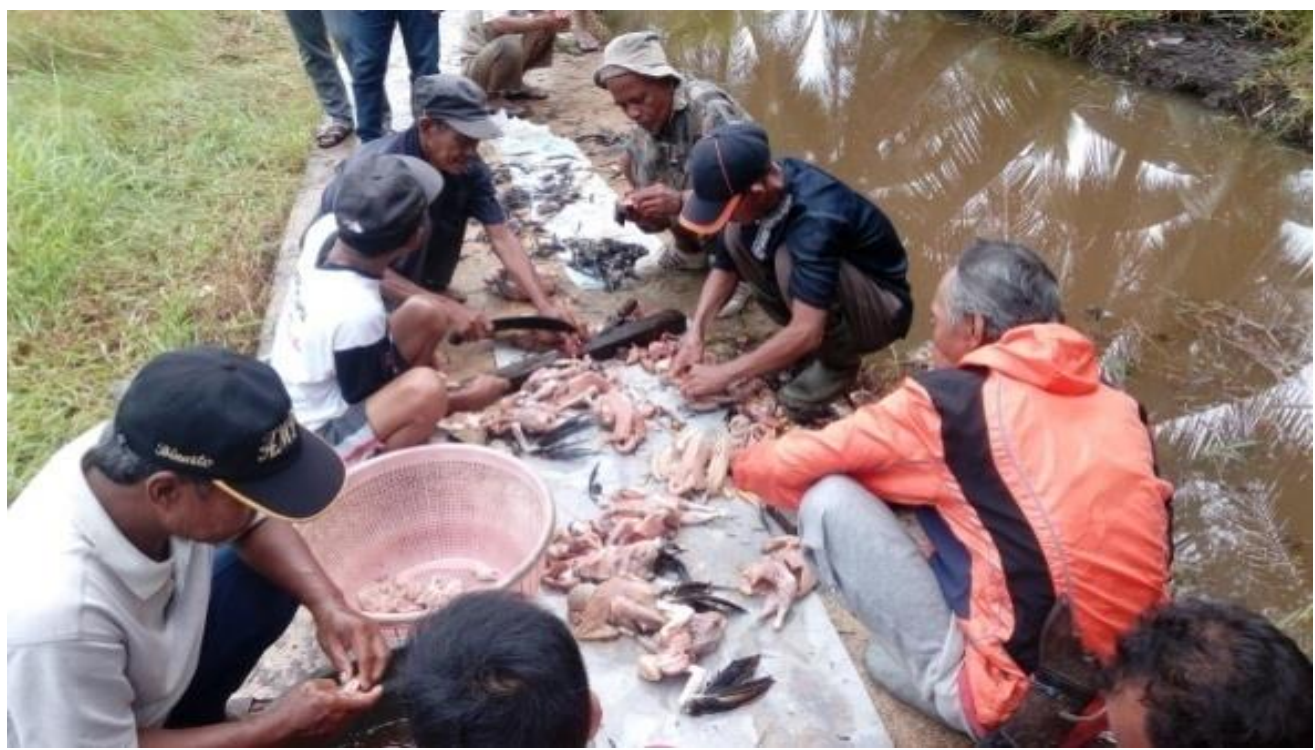

Figure.2

Cleaning the chicken (photo documentation of the writer)

After the furnace is lit, the cauldron is filled with boiling water and includes the seasoning that has been brought from the house into the cauldron.

KHATULISTIWA: Journal of Islamic Studies Vol. 9, No. 1. March 2019
DOI: 10.24260/khatulistiwa.v9i1.1255

Tudang Sipulung in Muslim Community of Peniti Luar (Identity, Islamic Value and Character Building) 


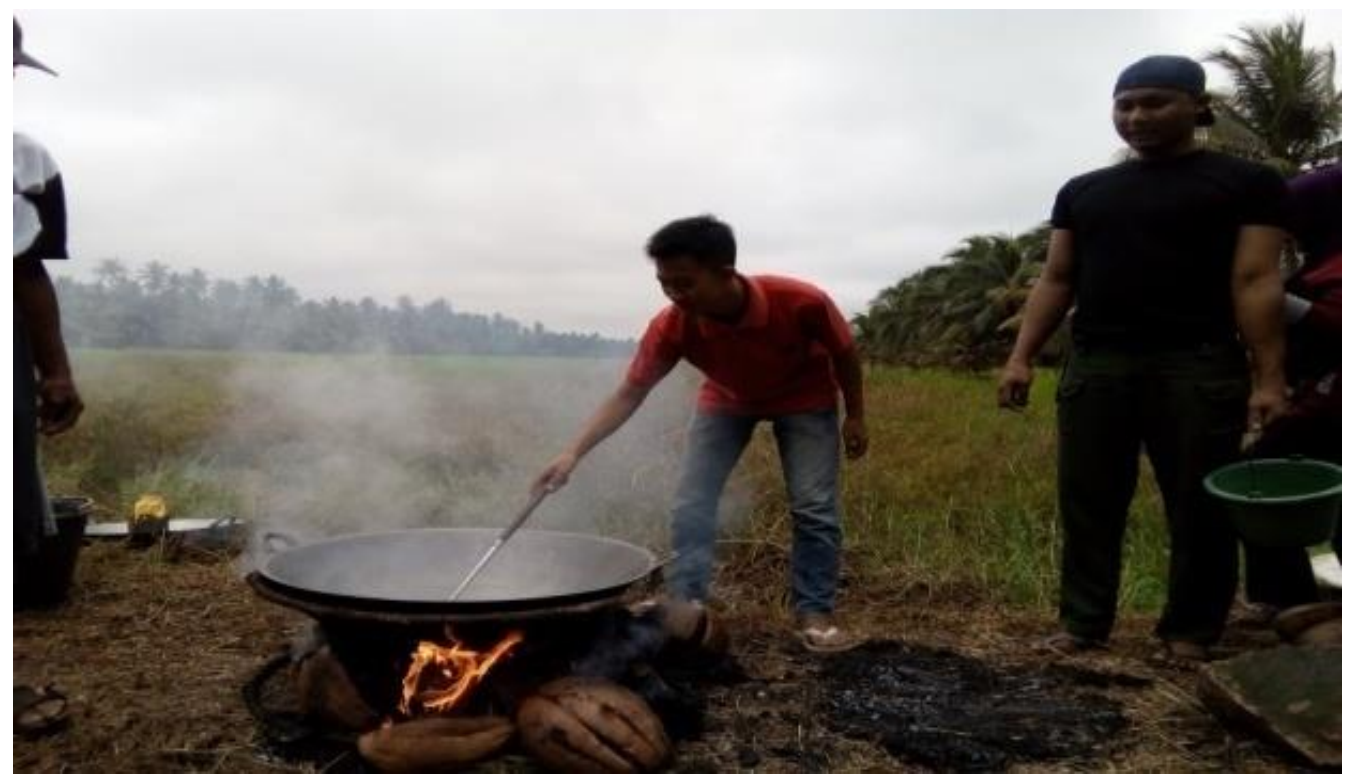

Figure.3 Chicken cooking place(photo author documentation)

If the chicken has been cleaned, then put it in a cauldron which has been filled with spices until boiling. The cooking process is carried out by men and there is work done, namely: stirring chicken, preparing equipment for eating, preparing bases for seating and banana leaves used to eat together. When the chicken has been cooked all the people gather by marching lengthwise and sitting facing each other. In addition, cooked food is placed in the middle position. Before eating together the religious leaders read the prayer first.

KHATULISTIWA: Journal of Islamic Studies Vol. 9, No. 1. March 2019
DOI: $10.24260 /$ khatulistiwa.v9i1.1255

Tudang Sipulung in Muslim Community of Peniti Luar (Identity, Islamic Value and Character Building) 


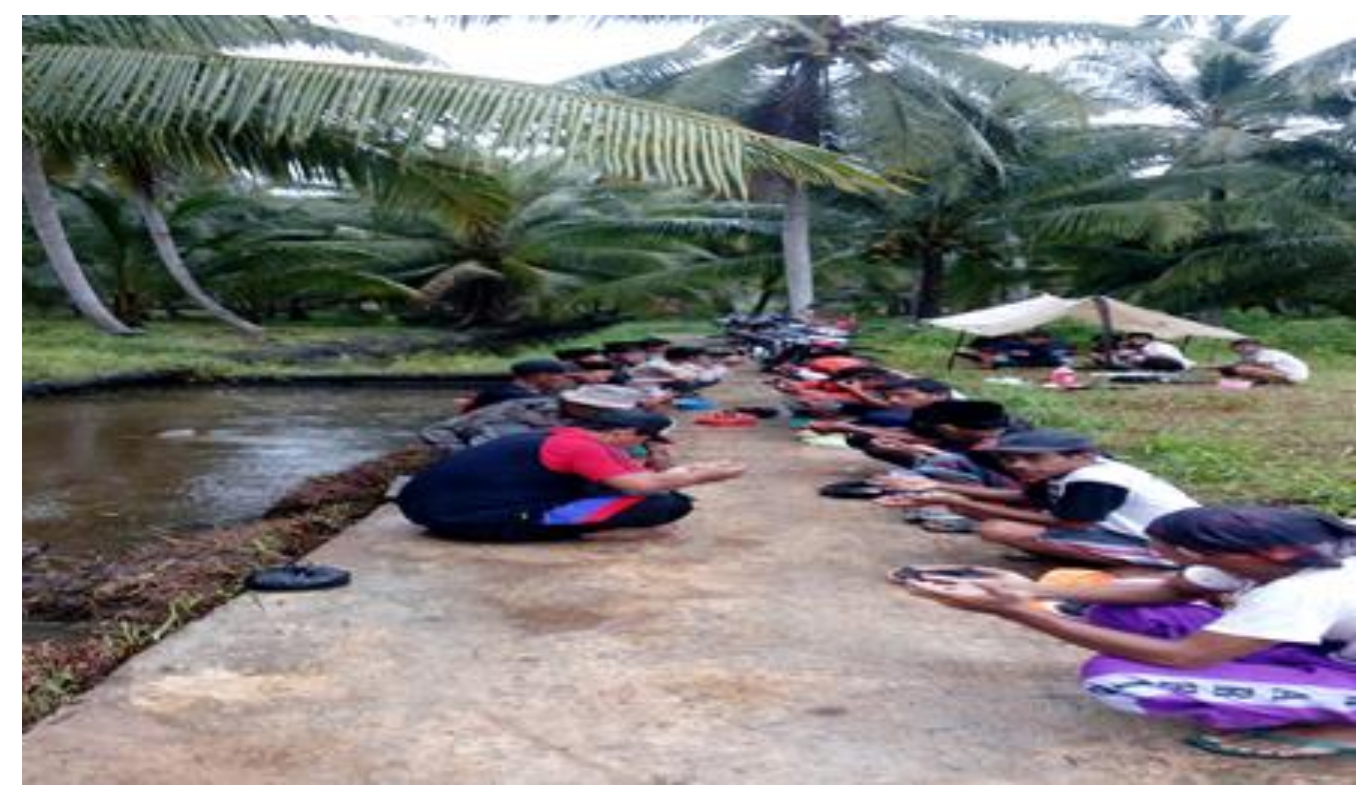

Figure 4. Reading prayers led by religious leaders(photo author documentation)

Mr Fauzi (44), a religious leader from Peniti Luar Village, prayed at the time of the Sipulung or eating food, in which the prayers of the Prophet Solomon, the prayer of the Prophet, and prayers of salvation. After the prayer was read, the whole community enjoyed food that had been cooked together.

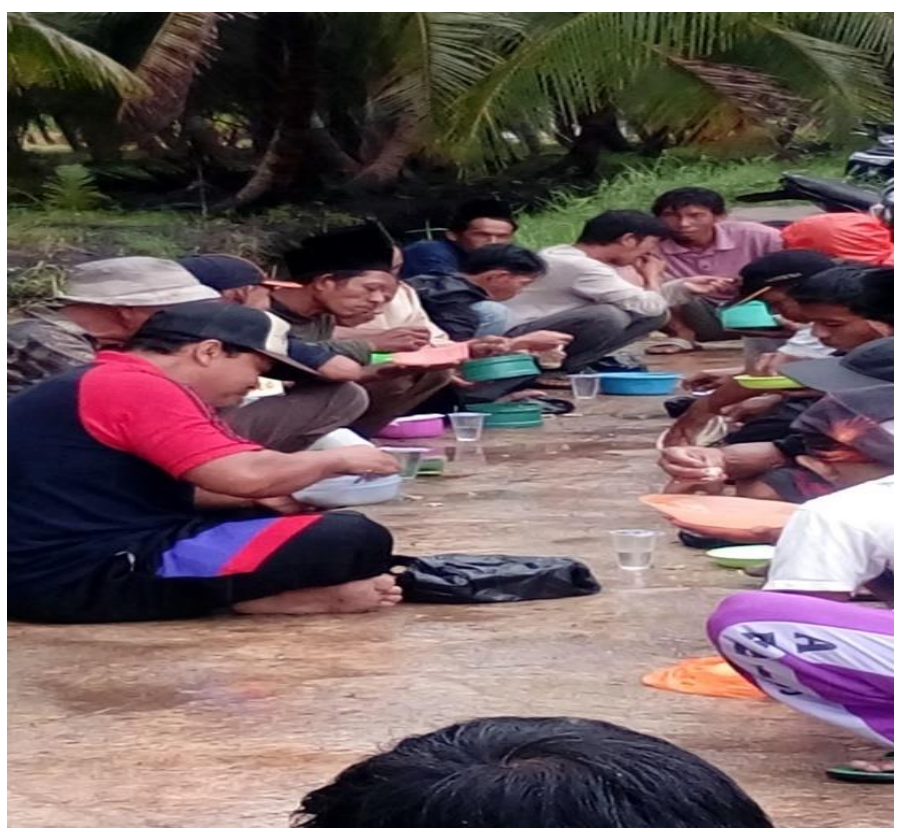

Figure.5 People eat together/Sipulung(photo author documentation)

KHATULISTIWA: Journal of Islamic Studies

Vol. 9, No. 1. March 2019
DOI: $10.24260 /$ khatulistiwa.v9i1.1255

Tudang Sipulung in Muslim Community of Peniti Luar (Identity, Islamic Value and Character Building) 
At the time of eating together the entire community ate each other facing each other and sharing the rice brought. After finishing the meal together, the whole community cleaned up the Sipulung places such as cooking pots, cooking stoves, dishes etc. So that the rice fields used in the lunch are clean of the rest of the event. After the sipulung meal was finished, the entire community returned to their homes and continued in the evening with a barzanjiactivity in the evening to recite the prayers for rice seeds to be planted.

According to Moh. Haitami Salim (2013: 60) generally the traditional Malay tribal traditional ceremonies are held as a manifestation of trust to deal with life changes (rites de passage), such as Reciting Barzanji that carried out for welcoming baby to death ceremony (Gunting Rambot/Cutting hair of baby, Naek Ayon/Riding the Swing for baby, and Tumbang Apam, etc. The Peniti Luar community has its own customs in reading Barzanji, one of which is to read rice seeds. The Barzanji reading in Peniti Luar Village is a series of Tudang Sipulung that are held in the morning. According to the informant Mr Ismail Sulaiman (67) Barzanji means praise to the Apostle, namely the king of the Prophet Muhammad. In addition, Barzanji can also be interpreted as a prayer and the narration of the history of the Prophet Muhammad, which is usually sung through tones and rhythms.

Barzanji readings on rice seeds are carried out in Surau found in the hamlet of Panca Bhakti, Peniti Luar. All people who have agricultural land gather in the Surau. Barzanji readings are performed by men while women prepare dishes usually various cakes to be served after the Barzanji reading is finished. The Barzanji reading was carried out on the same day at the Sipulung meal. If a Sipulung tradition is done in the morning, Barzanji will be held at night. However, the Barzanji reading is a series of events from the Sipulung.

After the Salat Isya all the village people gathered in Surau carrying the rice seeds to be sown. Before the Barzanji event, the whole community sat in a circle and leaned on the surau wall. After that the community-owned rice is placed in the middle. The rice to be recited by Barzanji is inserted into the collection of wax and light the candle.

KHATULISTIWA: Journal of Islamic Studies

Vol. 9, No. 1. March 2019
DOI: $10.24260 /$ khatulistiwa.v9i1.1255

Tudang Sipulung in Muslim Community of Peniti Luar (Identity, Islamic Value and Character Building) 


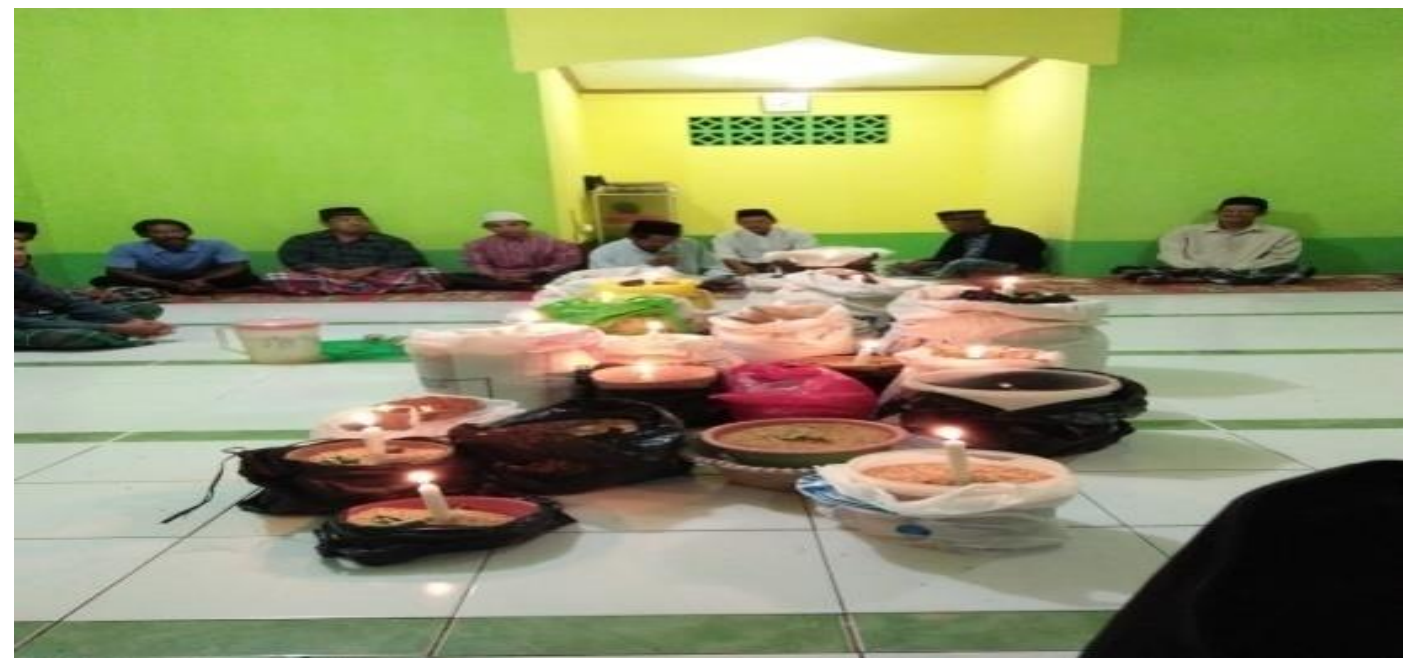

Figure 6. Putting Candles in Rice(photo author documentation)

After lighting the candles the religious leader reads a prayer facing the rice seed. In addition, reading prayers of religious leaders also carried out bepapas processions on community rice seeds. After finishingof reading prayers and bepapas on rice seeds then continued reading Barzanji and followed by all the people in the surau. The implementation of Barzanji also has stages in the series of events. According to Mr. Fauzi (44) Every thing that is done must begin with an intention including Barzanji quoted from the informant's submission when interviewed: "I intend to read the barzanji shalawatto expect the blessing of Allah SWT. Yes, Allah protect my family like the safetyfor the family and the Prophet Muhammad. "After that they read the next intention of reading Al-Fatihah led by religious leaders and followed by all the pilgrims who joined Barzanji. Furthermore, by reading the prayer to the prophet Muhammad, that is "Shollu'ala al-Nabi Muhammad!" and answered by the congregation with Allahuma sholli'alaih.

After reciting the prayer, the recitation was followed by a sermon led by religious leaders and followed by all the worshipers. At the time of doing all the pilgrims stand and face each other. According to Mr. Burhanuddin (46) the purpose of all pilgrims stood in honor of the Prophet Muhammad. Every prayer session is always led by religious leaders and all worshipers follow and answer from the prayer. After completing as long as all pilgrims are allowed to sit back. Continued reading Barzanji performed by pilgrims in turns. According to the informant, Mr. Fauzi (44) reading the book Barzanji in its implementation consisted of 1-

KHATULISTIWA: Journal of Islamic Studies

Vol. 9, No. 1. March 2019
DOI: 10.24260/khatulistiwa.v9i1.1255

Tudang Sipulung in Muslim Community of Peniti Luar (Identity, Islamic Value and Character Building) 
6 articles in the Barzanji book. The reading of the article was read by the congregation in turn. At the time of reading the Barzanji all worshipers are advised not to speak. If you want to talk, the congregation must say the subhanallah 80 times and continue to read the surah al-ikhlas 80 times. However, there are still many worshipers who do not know that in reading Barzanji they should not speak. Although there is a speech from Mr. Fauzi (44) as a religious leader, he does not order the worshipers to recite the "subhannallah" 80 times and surah al-Ikblas. The aim is totrain community and recommendations not to speak only from the attitude of religious leaders who did not speak at the time of implementation.

After reading the prayer and Barzanji, all the villagers returned to save their rice seeds. Next, women deliver cakes to be served to all worshipers. All worshipers sit in a circle to enjoy the cake served. For men enjoying the dishes in surau while the women sit behind the surau or the surau breezeway. Based on the observations of the researchers the cakes served by women consist of various cakes. Cakes that are served are homemade results from the whole community so that the cakes served are also varies.

\section{The Value of Tudang Sipulung Tradition in Muslim Community of Peniti Luar Village}

Moh. Haitami Salim (2013: 272) value is a behavioral reference, then the value in Islam is the whole system of life that refers to Islamic teachings based on the Qur'an and the Sunnah of the Prophet. Basic of Islamic values can be called shari'ah, which is all the provisions of Allah that govern human life. Islamic education lies in the realization of a complete attitude of surrender to Allah, both individual, society, and as a whole(Muslihah, 2010: 22). Therefore, speaking of Islamic religious education, both its meaning and purpose must refer to the basic of Islamic values and not justify forgetting social ethics and social morality (Arifin, 2008: 136).

Tradition in Islamic education is as a cultural heir. This is relevant to Ramayulis and Samzul Nizar (2009: 92) who assume Islamic education as a means of transmitting the basic elements of culture from one generation to the next, so that people's identities are maintained and guaranteed in the challenges of the times. In the Peniti Luar Village the value of Islam is in touch with the traditions of the local community so that it is attached to the identity of the community, so that in the tradition of the Peniti Luar Village people are no longer concerned

KHATULISTIWA: Journal of Islamic Studies

Vol. 9, No. 1. March 2019
DOI: 10.24260/khatulistiwa.v9i1.1255

Tudang Sipulung in Muslim Community of Peniti Luar (Identity, Islamic Value and Character Building) 
with ethnic equality but rather the equality of Islamic values that are carried out and become part of their character.

According to Peursen (1984: 11) tradition is not something that cannot be changed, tradition can be combined with a variety of human actions. Therefore, human beings determine to accept, reject, and change tradition. The Islamic values contained in the tradition of the Tudang Sipulung are as follows:

\section{Thanksgiving}

The initiation of farming in the tradition of the warrior community of Peniti Luar community is one of the expressions of gratitude to Allah SWT for the land owned to grow rice. Thanksgiving in Syamsul Kurniawan (2015: 128) is thankful for the meaning of thankfulness. According to the term is to use all the blessings that Allah has given in accordance with the provisions that have been governed and determined by Him. According to Mr. Samsudin (40) said that in the tradition of Tudang Sipulungis looking for blessings in the process of planting rice. Bringing chicken is not to give genies eat but only the rules that apply in the community of Peniti Luar and not the form of shirke(associating God with the other) and carrying chicken is not an obligation. Jumadi (39) said that in the tradition of eating rice, the aim was to ask Allah for help so that the planted rice would thrive without many disturbing pests. As a normal human being, it should be right to remember that there are some who are unseen, both genie and others. While Mr. Fauzi (44), the purpose of eating sipulung is to thank Allah SW'T for having a new rice planting season. Besides that, eating a sipulung to remind the genie not to disturb the human race by reading the prayer of the Prophet Solomon, and salvation. Prayer is for asking protection from Allah SWT. While eating Sipulung is only a form of increasing friendship between communities and seeking blessings from Allah SWT.

\section{Silaturrahim Value}

Based on the results of the observations of the researcher that in the implementation of the tradition carried out by the people of the Peniti Luar Village is a

KHATULISTIWA: Journal of Islamic Studies

Vol. 9, No. 1. March 2019
DOI: $10.24260 /$ khatulistiwa.v9i1.1255

Tudang Sipulung in Muslim Community of Peniti Luar (Identity, Islamic Value and Character Building) 
harmony value. Syamsul Kurniawan (2015: 126) explained that friendship is also an important part of hablum minal-nas (strengthening humanitarian relationships and worth of worship) that even friendship is not only done with people who have good relations with us, but also with people whose relationships are not good with us

Based on information from Mr. Jumadi (39) the activities of Tudang Sipulung are only done once a year. So that the community is very enthusiastic in carrying out a Sipulung meal program in the rice fields. In addition to gathering together many stories and experiences conveyed by the community at the time the Tudang Sipulung activity was carried out. Based on the observations that the community does not only implement the tradition but also share stories about agricultural issues as well as links to other common things, such as village, politics, religion and other developments.

Eating Sipulung or eating together done by the community of the Peniti Luar Village also fosters kinship between communities. Communities with each other look familiar and have a very high bond of brotherhood in eating together, not only during the implementation of the sipulung meal, when they ate the cake together, but also during the Barzanji program in Surau. Based on the statement of Muhammadiyah (22), when the whole community gathered in the traditional ceremony for the tributary of the Tudang Sipulung, which continued with Barzanji, the community made the people more familiar. The brotherhood and togetherness that exist in the community will be seen in mutual cooperation activities and religious traditions, one of which is eating Sipulung and Barzanji.

\section{Mutual value}

From the start of the implementation of the traditional sipulung meal everything was done jointly carried out by the Muslim community in the Peniti Luar Village. Both of the cooking utensils such as stoves and cauldrons are all owned by the people who lend equipment in the tradition of sipulung food. In addition, the land used in the implementation is also owned by one of the Peniti Luar communities who provide land in the tradition of eating Sipulung. Bringing chicken and rice from home is a manifestation of

KHATULISTIWA: Journal of Islamic Studies Vol. 9, No. 1. March 2019
DOI: $10.24260 /$ khatulistiwa.v9i1.1255

Tudang Sipulung in Muslim Community of Peniti Luar (Identity, Islamic Value and Character Building) 
mutual cooperation between communities. For people who are not able to carry chickens, they are not obliged to bring and keep gathering together in eating spoons.

Mahmoud M. Ayoub (2004: 258) says Unity in Muslims must also be a benefit, namely a harmonious relationship system with higher and noble goals than just a group of strong and potential people. Unity in Islam is a form of cooperation. Allah Almighty said: "And help you in (doing) kindness and piety, and do not you help in sinning and transgression" (Q.S. AlMa'idah [5]: 2).

Mr. Jumadi (39), one of the RT heads, said that both from the event equipment such as cooking spices each community brought from home as well as chicken and rice. In addition to the stoves and cauldrons, the community usually lends voluntarily to eat cloves. From the process of cleaning the chicken until cooking everything is done together. Based on observations from researchers, from the beginning the series of Sipulung food programs began until it was completed jointly by the men of the Peniti Luar Village community. Each community works without orders from religious leaders.

In addition they work together with activities to enjoy food that has also been cooked together and facing each other. After completing the event, the whole community cleared the agricultural land as well as cleaning the remaining chicken manure and the rest of the cooking done cleanly. The implementation of Barzanji was also carried out in mutual cooperation, it seemed visible from the implementation to the beginning. Each community brings cakes to be eaten with all worshipers without being ordered by religious leaders and community leaders.

Based on information from Mr. Jumadi (39) bringing cake is an initiative of the community itself and not an order or even an obligatory, not only do men of women help in the Barzanji program, but also they are preparing dishes to be served. Women prepare drinks and food that the community has brought. Women gather in one of the houses of the community not far from Surau which holds the Barzanji event. Based on the observations, the whole community cleaned up the surau while the women washed the dishes after the event. Cleaning up the rest of the event equipment carried out by women together. Whereas men clean the surau.

KHATULISTIWA: Journal of Islamic Studies Vol. 9, No. 1. March 2019
DOI: $10.24260 /$ khatulistiwa.v9i1.1255

Tudang Sipulung in Muslim Community of Peniti Luar (Identity, Islamic Value and Character Building) 


\section{Moral Value}

One of the values exemplified by the community towards the exemplary young generation is morality. Based on the observations of the researchers that both the tradition of eating Sipulung and the reading of Barzanji and prayers for rice seeds the community exemplifies noble character, especially to the younger generation. Not a few children and young people in the Peniti Luar Village follow the tradition of eating Sipulung and Barzanji. In addition, the implementation of the Barzanji reading can also be exemplified to the younger generation. Based on information from Mr. Ismail Sulaiman (67) said in the Barzanji book there is a story of the journey of the prophet Muhammad SAW from childhood to the death of the prophet Muhammad SAW. Many noble moral values are contained in the contents of the book Barzanji. The nature of honesty and manners can be exemplified by children and adolescents as well as youth from the Peniti Luar village.

As explained by Mr. David (38), it was revealed that the Barzanji reading was expected that children and adolescents could take lessons from the life journey of the Prophet Muhammad. So that his hopes by carrying out the Barzanji reading of the younger generation of Peniti Luar Village were avoided from promiscuity and made the Prophet Muhammad SAW as a role model for children and adolescents. Introducing the journey of the Prophet Muhammad by reading the Barzanji book to children to get to know the figure of the Prophet Muhammad. Moreover, in this day and age there are many challenges experienced by the younger generation so that they do not understand the journey of the prophet Muhammad SAW especially his moral and life to be used as an example in facing challenges in the current era.

Apart from the contents of the Barzanji book, examples of noble morality were also shown by the community of the Peniti Luar Village by cleaning up the Surau after the Barzanji event and cleaning the rice fields after they had done the sipulung. In the implementation of sipulung to remind Jin not to disturb humans is also one example of morality to the younger generation. In addition to have morals towards fellow human beings, they must also have good character towards supernatural beings, including Genie,

KHATULISTIWA: Journal of Islamic Studies

Vol. 9, No. 1. March 2019
DOI: $10.24260 /$ khatulistiwa.v9i1.1255

Tudang Sipulung in Muslim Community of Peniti Luar (Identity, Islamic Value and Character Building) 
as the creation of Allah SWT.The tradition of eating sipulung and reading Barzanji on rice seeds that will be sown is one of the traditions that are beneficial for young people. The young generation does not have to go far to look for good examples of morality but also has been found in Islamic values carried out by local people.

\section{Relevance Of Tudang Sipulung in Building Characters}

As the author has explained before, that in the implementation of scavenger sheds build the character of the Muslim community in the Peniti Luar Village. As far as researchers observe, it contains Islamic values so that the spirit of influence in building character. This can be appreciated, considering that human beings are inseparable from the teachings of their religion. According to Moh. Haitami Salim (2013: 271) the community adheres to social values, about what is considered good and what is considered bad by the community. To determine good and bad, appropriate or inappropriate must go through a process of weighing. This is greatly influenced by the culture adopted by the community. Regardless of who influences and who is influenced, Moh. Haitami Salim (2012: 34) this phenomenon at least illustrates that, there has been contact between culture and society so that cultural contact applies acculturation to culture.

In Peniti Luar, Islamic values come into contact with local wisdom so that the character of the Muslim community is formed in the Peniti Luar Village. So that Islamic values adhere to their identity and become a marker of them as Muslim communities who are obedient in carrying out Islamic teachings. This is why Islamic values and local wisdom in this case of the Tudang Sipulungtradition has an influence in building character.

KHATULISTIWA: Journal of Islamic Studies

Vol. 9, No. 1. March 2019
DOI: 10.24260/khatulistiwa.v9i1.1255

Tudang Sipulung in Muslim Community of Peniti Luar (Identity, Islamic Value and Character Building) 


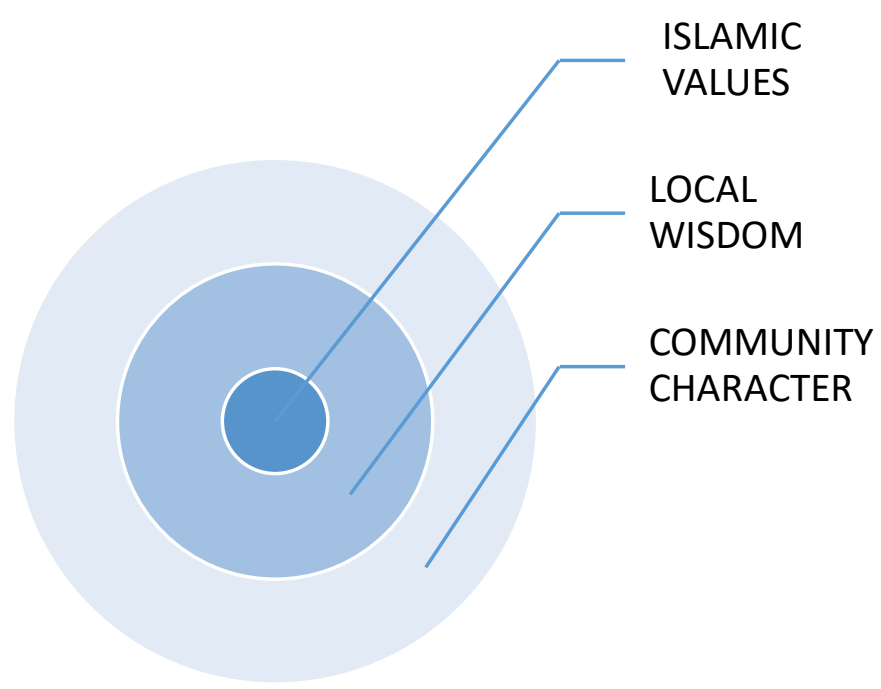

Figure.7Islamic values, local wisdom, and community character formation.

The correlationamong Islamic patterns, local wisdom and the character of the people in the picture shows that Islam is a source of value. Therefore, developing local wisdom is inspired by Islamic values so that in its implementation it must not conflict with the principles of Islamic teachings. From here it will form the character of the community as the executor of traditions that carry out traditions in accordance with Islamic values.

\section{CONCLUSION}

The local wisdom of the Peniti Luar Village in this case is the tributary of Tudang Sipulung run by their marker community, as Muslim communities who are obedient in carrying out the teachings of Islam. Local wisdom that is run by Muslim communities runs lively and tends to be hybrid. So that the Tudang Sipulung is an inseparable part and becomes the identity of the Muslim of Peniti Luar community. Sipulung is carried out in community-owned fields and carried out by men. After that, followed by reading Barzanji and reciting prayers on rice seeds belonging to the Muslim community of Peniti Luar. Everything is a series of processes in the implementation of Tudang Sipulung.

There are Islamic values in the implementation of Tudang Sipulung, such as, the value of gratitude, the value of friendship, the value of mutual cooperation, and moral values. The Tudang Sipulung is a local wisdom that is carried out in starting rice farming in Muslim

KHATULISTIWA: Journal of Islamic Studies

Vol. 9, No. 1. March 2019
DOI: 10.24260/khatulistiwa.v9i1.1255

Tudang Sipulung in Muslim Community of Peniti Luar (Identity, Islamic Value and Character Building) 
communities. Islamic values in the tradition of sipulung that are embraced by Muslim communities in Peniti Luar is an identity and part of the community that practices Islamic values in social life. In Peniti LuarTudang Sipulungtradition is carried out every time opening up agricultural land. This local wisdom has been carried out from time to time without any encouragement and coercion. The Muslim Community of Peniti Luarvillage runs the Tudang Sipulung only for the practice of the teachings of Islam and as the adab(kind of Islamic ethics) of a Muslim both to the creator of Allah SWT, to His creatures human and genie, and to the Prophet. So that the Islamic values that have been carried out have become a handle and a part of everyday life. Seen from the many benefits for the Peniti Luar community, one of them is an attitude of willingness and self-awareness to maintain local wisdom that has been carried out in stages.

The tradition of the Tudang Sipulung developed as the local wisdom of the Muslim community in the Peniti Luar Village was inspired by Islamic values, so that in its implementation it was in line with the principles of Islamic teachings. This is where the character of Muslim society will be formed as the executor of tradition. In this context, Tudang Sipulungtradition is relevant to character building.

\section{BIBLIOGRAPHY}

Arifin. 2008. Ilmu Pendidikan Islam Tinjauan Teoritis dan Praktis Berdasarkan Pendekatan Interdisipliner. Jakarta : PT Bumi Aksara.

Arizal Mutahir.2011.Intelektual Kolektif Pierre Bourdieu:Sebuah Gerakan Melawan Dominasi, Yogyakarta: Kreasi Wacana.

Budi Santoso, Bahasa dan Identitas Budaya, dalam Jurnal Sabda, Vol. 1, No.1, September 2006. C.A. Peursen.1984. Strategi Kebudayaan, Yogyakarta: Kanisius-BPK Gunung Mulia Eneng Muslihah. 2010. Ilmu Pendidikan Islam. Jakarta : Diadit Media Hasse J.2009. Dinamika Masyarakat dan Kebudayaan Kontemporer. Yogyakarta: Pustaka Pelajar Hermansyah.2015. Islamdan Melayu di Borneo. Pontianak: IAIN Pontianak Press.

Mahmoud M.Ayoub 2004. Islam: Antara Keyakinan \& Praktek Ritual, Yogyakarta: AK Group

KHATULISTIWA: Journal of Islamic Studies

Vol. 9, No. 1. March 2019
DOI: $10.24260 /$ khatulistiwa.v9i1.1255

Tudang Sipulung in Muslim Community of Peniti Luar (Identity, Islamic Value and Character Building) 
Mohammad Adib, "Agen dan Struktur dalam Pandangan Pierre Bourdieu." dalam Jurnal BioKultur, Volume 2, Nomor 1, 2012.

Moh. Haitami Salim.2013. Nilai-Nilai Pendidikan Islam Dalam Upacara Adat Melayu Pontianak. Pontianak: STAIN Pontianak Press.

Moh. Haitami Salim.2012. Islam dan Etnisitas di Kalimantan Barat: Menggali Nilai-Nilai Kearifan Lokal Masyarakat Muslim di Kalimantan Barat, Pontianak: STAIN Pontianak Press.

PierreBourdieu.2012. Arena Produksi Kultural Sebuab kajian Sosiologi Budaya, Yogyakarta: Kreasi Wacana

Ramayulis \& Samsul Nizar.2009. Filsafat Pendidikan Islam. Jakarta: Kalam Mulia

Rizal Mustansyir.2015. Kearifan Lokal Masyarakat Melayu Sambas Dalam Tinjauan Filosofis. Yogyakarta: Fakultas Filsafat UGM

Saripaini \& Yusriadi, Identitas Orang Bugis di Dabong, Kalimantan Barat, dalam Jurnal Khalustiwa Vol.6, No.2, September 2016.

Syamsul Kurniawan, Serapah Dalam Masyarakat Melayu Kampung Saigon Kota Pontianak, dalam Jurnal Religi, Vol.IX, No. 1 Januari 2013.

Syamsul Kurniawan,ed. 2015. Tradisi dan Kepercayaan Umat Islam di Kalimantan Barat. Yogyakarta: Samudera Biru.

Syamsul Kurniawan \& Bayu Suratman, Bertani Padi Orang Melayu Sambas: Kearifan Lokal, Nilai-Nilai Islam, dan Character Building, dalam Jurnal Analisis Vol,18, No.2, Desember 2018.

Syamsul Kurniawan, Globalisasi, Pendidikan Karakter Dan Kearifan Lokal Yang Hybrid Islam Pada Orang Melayu Kalimantan Barat, dalam Jurnal Penelitian, Vol.12, No.2, Agustus 2018.

Wewen Darmawan, Amrazi Zakso, Gusti Budjang, Memudarnya Nilai-Nilai Budaya 'Belalek'

Dalam Bidang Pertanian Pada Masyarakat Pedesaan.Jurnal Pendidikan Dan Pembelajaran Volume 5, Nomor, 3, 2016.

Yusriadi, "Identitas Orang Melayu di Hulu Sungai Sambas", dalam Jurnal Khalustiwa, Vol 5, No1, Maret 2015.

Zainuddin Hudi Prasojo.2009. Dinamika Masyarakat dan Kebudayaan Kontemporer. Yogyakarta: Pustaka Pelajar.

KHATULISTIWA: Journal of Islamic Studies

Vol. 9, No. 1. March 2019
DOI: $10.24260 /$ khatulistiwa.v9i1.1255

Tudang Sipulung in Muslim Community of Peniti Luar (Identity, Islamic Value and Character Building) 